\title{
Stability of Lithium Aluminate in Reducing and Oxidizing Atmospheres at $700^{\circ} \mathrm{C}$
}

Su Jeong $\mathrm{Heo}^{\mathrm{a}}$, Boxun $\mathrm{Hu}^{\mathrm{a}}$, Venkata Manthina ${ }^{\mathrm{a}}$, Abdelkader Hilmi ${ }^{\mathrm{b}}$, Chao-Yi Yuh ${ }^{\mathrm{b}}$, Arun Surendranath ${ }^{\mathrm{b}}$, and Prabhakar Singh ${ }^{\mathrm{a} *}$

${ }^{a}$ Center for Clean Energy Engineering, Department of Materials Science and Engineering, University of Connecticut, 44 Weaver Road, Storrs, CT 06269-5233, United States

${ }^{b}$ FuelCell Energy, Inc., 3 Great Pasture Rd, Danbury, CT 06813, United States

* Corresponding author. 44 Weaver Road, Storrs, CT 06269-5233, USA. Tel.: +1 $8604868379 ;$ fax: +1 860486 8378.

E-mail address: singh@engr.uconn.edu (P. Singh).

(C) 2016. This manuscript version is made available under the Elsevier user license http://www.elsevier.com/open-access/userlicense/1.0/ 


\begin{abstract}
The stability of lithium aluminate $\left(\mathrm{LiAlO}_{2}\right)$ powders has been studied under reducing $\left(4 \% \mathrm{H}_{2}-\mathrm{N}_{2}\right)$ and oxidizing (Air) atmospheres at $700^{\circ} \mathrm{C}$. While $\mathrm{XRD}$ results show the raw $\alpha$ $\mathrm{LiAlO}_{2}$ samples contain a minor fraction of $\mathrm{LiAl}_{2}(\mathrm{OH})_{7} \cdot 2 \mathrm{H}_{2} \mathrm{O}$ and $\mathrm{LiAlO}_{2} \cdot 0.25 \mathrm{H}_{2} \mathrm{O}$ phases, high-temperature XRD study shows that $\mathrm{LiAl}_{2}(\mathrm{OH})_{7} \cdot 2 \mathrm{H}_{2} \mathrm{O}$ may have decomposed at $700^{\circ} \mathrm{C}$ to $\gamma$ $\mathrm{LiAlO}_{2}$ and $\mathrm{LiAlO}_{2} \cdot 0.25 \mathrm{H}_{2} \mathrm{O}$ to $\alpha-\mathrm{LiAlO}_{2}$. Surface morphological studies show the samples consist of porous $\mathrm{LiAlO}_{2}$ spherical agglomerates with interconnected nanoparticles. The XPS analyses indicate that the powder surface $\mathrm{Li} / \mathrm{Al}$ ratio decreases after exposure to reducing atmosphere whereas much less change to the oxidizing atmosphere. The binding energy of Al $2 p$ peak also changes in the high-temperature reducing and oxidizing environments, indicating the presence and co-existence of different oxidation states of Al species on the surface. The color of $\mathrm{LiAlO}_{2}$ powder, examined visually, changed from white to gray after reduction and back to white after re-oxidation, indicating the likelihood of generation of non-stoichiometry under reducing atmosphere.
\end{abstract}

\title{
Keywords
}

Lithium aluminate; Color change; Crystal structure; Phase change; Surface morphology 


\section{Introduction}

Lithium aluminate $\left(\mathrm{LiAlO}_{2}\right)$ has been extensively used for over three decades as a ceramic constituent material of the electrolyte matrix structure in molten carbonate fuel cell (MCFC) stacks for stationary power generation [1, 2]. MCFCs operate at intermediate temperatures in the range of $550-650^{\circ} \mathrm{C}$ and offer high electrical and combined heat and power (CHP) efficiency (>47\% single-cycle electrical and $>85 \% \mathrm{CHP}$ ). A wide variety of fuels derived from renewable resources (bio-fuels) and fossil fuels (coal and natural gas) have been successfully utilized in MCFCs. Although 40,000-50,000 hours of operation has been demonstrated at MW class MCFCs, further enhancements in operating life time and cell performance stability are considered important for accelerating large scale commercialization and global market penetration. The porous electrolyte matrix, which acts as an electrolyte retainer, has been considered as one of the most critical stack component impacting cell life and performance; continuous particle coarsening and structural changes could result in reduced capability of electrolyte retention, faster electrolyte loss and increased gas crossover [3]. $\mathrm{LiAlO}_{2}$ exists in three different allotropic forms: the hexagonal $\alpha-\mathrm{LiAlO}_{2}$, tetragonal $\gamma-\mathrm{LiAlO}_{2}$ and monoclinic $\beta-\mathrm{LiAlO}_{2}[4]$ of which the $\gamma-\mathrm{LiAlO}_{2}$ is the stable phase at higher temperatures, while $\alpha$ - and $\beta$-LiAlO 2 phases show transformation to the $\gamma-\mathrm{LiAlO}_{2}$ at elevated temperatures [5, 6]. For example, at very-high temperatures (e.g., $937^{\circ} \mathrm{C}$ ), $\alpha-\mathrm{LiAlO}_{2}$ can transform to $\gamma-\mathrm{LiAlO}_{2}$ in air after 40 hours [7]. Particle coarsening and phase transformation of $\mathrm{LiAlO}_{2}$ have been reported as one important cause for in-cell electrolyte depletion in MCFC [8]. Although $\gamma-\mathrm{LiAlO}_{2}$ has initially been considered stable in MCFC, its instability has been revealed to result in the accelerated electrolyte loss and cell failure in long-term cell operation [9]. Since mid-1990s $\alpha$ $\mathrm{LiAlO}_{2}$ has been recognized as a more stable matrix support material for current commercial 
MCFC deployment [10]. Nevertheless, fundamental understandings of its stability still need to be investigated for helping designing approaches to achieve durability for $\geq 10$-year service life.

$\mathrm{LiAlO}_{2}$ has also found application as a solid tritium breeding material in nuclear fusion reactors due to its excellent thermochemical and mechanical stability at high temperature and favorable irradiation behavior [1, 2]. Apart from application in nuclear systems, $\mathrm{LiAlO}_{2}$ has also found application as an excellent luminescent material [11]. $\gamma-\mathrm{LiAlO}_{2}$ provides an attractive red phosphor for artificial illuminations [12].

A number of synthesis processes including conventional solid-state reactions, sol-gel processing, co-precipitation and combustion synthesis have been extensively used for the preparation of $\mathrm{LiAlO}_{2}$ powder. Solid-state synthesis in the range of $370^{\circ} \mathrm{C}$ to $1000^{\circ} \mathrm{C}$ has been reported to lead to the formation of a mixture of $\mathrm{LiOH}$ and a lithium dialuminate, depending on the calcination temperature $[13,14]$. The process was found difficult for the synthesis of pure lithium aluminate with controlled size and morphology due to partial evaporation of lithium at higher temperatures and contamination from grinding operations [15]. $\alpha-\mathrm{LiAlO}_{2}$ has been synthesized using oxide and salt precursors. A mixture of $\mathrm{Li}_{2} \mathrm{CO}_{3}$ and $\mathrm{Al}(\mathrm{OH})_{3}$ were dried at $60^{\circ} \mathrm{C}$ for 24 hours followed by heat-treated at $650^{\circ} \mathrm{C}$ for 24 hours in a pure $\mathrm{CO}_{2}$ atmosphere. The final powders were produced by eliminating the residual carbonate by washing [16]. Formation of minor-phase lithium aluminum oxide hydrate, $\mathrm{LiOH} \cdot 2 \mathrm{Al}(\mathrm{OH})_{3} \cdot 2 \mathrm{H}_{2} \mathrm{O}\left(\right.$ or $\left.\mathrm{LiAl}_{2}(\mathrm{OH})_{7} \cdot 2 \mathrm{H}_{2} \mathrm{O}\right)$ during powder synthesis was found to transform easily to $\gamma-\mathrm{LiAlO}_{2}$ during exposure to nitrogen atmosphere at elevated temperatures [17].

Sol-gel technique has been used for preparing $\gamma-\mathrm{LiAlO}_{2}$ utilizing the hydrolysis of lithium and aluminum alkoxide followed by calcination at temperature of $550^{\circ} \mathrm{C}$ [17]. The technique showed the limitation in terms of instability of precursors, precise control of reaction steps and 
use of expensive reactants. Use of co-precipitation technique provided pure $\gamma$ - $\mathrm{LiAlO}_{2}$ in the presence of nonionic surfactant after calcination at $950^{\circ} \mathrm{C}$ [15]. The combustion synthesis technique using glycine nitrate-urea reactants was also found suitable for synthesizing $\gamma-\mathrm{LiAlO}_{2}$ $[18,19]$.

As mentioned earlier, sufficient $\mathrm{LiAlO}_{2}$ stability under MCFC operating environment is essential to assure long-term electrolyte retention for stable cell resistance and performance. $\mathrm{LiAlO}_{2}$ in matrix experiences both reducing anode and oxidizing cathode atmospheres. However, detailed $\mathrm{LiAlO}_{2}$ structure thermal stability under various gas atmospheres have been reported in the literature only to a limited extent. Discoloration of $\gamma-\mathrm{LiAlO}_{2}$ powders have been reported due to the presence of residual amorphous carbon-containing compounds resulting from incomplete oxidation of the glycine-urea by the combustion synthesis technique [20]. Color change from white to dark blue in oxides such as $\mathrm{Li}_{2} \mathrm{TiO}_{3}$ exposed to reducing conditions has been attributed to oxygen non-stoichiometry and formation of vacancies and compound such as $\mathrm{Li}_{2-\mathrm{x}} \mathrm{TiO}_{3-\mathrm{y}}[21]$.

In the present paper, we have investigated the structural and chemical stability of $\alpha$ $\mathrm{LiAlO}_{2}$ under reducing and oxidizing atmospheres at $700^{\circ} \mathrm{C}$. We further develop fundamental understandings of the effect of crystalline structure, surface composition, and morphology on thermal stability.

\section{Experimental}

\subsection{Materials and Methods}

The $\mathrm{LiAlO}_{2}$ powder samples were prepared by solid-state synthesis method reported by Choi, et al. [16]. The precursor materials, $\mathrm{Al}(\mathrm{OH})_{3}\left(>99.9 \%\right.$ pure) and $\mathrm{Li}_{2} \mathrm{CO}_{3}(>99.9 \%$ pure), were mixed with deionized water in the different molar ratio to control $\mathrm{Li} / \mathrm{Al}$ ratio by ball milling. Uniformly dispersed mixtures were subsequently dried at $110^{\circ} \mathrm{C}$ for 24 hours. The dried powder 
cake was calcined at $600-800^{\circ} \mathrm{C}$ for $12-24$ hours in ambient stagnant air. The calcined powders are stored in desiccator. The powder samples A and B are essentially pure $\alpha-\mathrm{LiAlO}_{2}$ but contain small amounts of minor phases due to variation in the preparation conditions. The experimental set up used for conducting the long-term exposure tests is shown in Fig. 1. High-temperature exposure studies in controlled environments were conducted at $700^{\circ} \mathrm{C}$ for 100 hours in crucibles made from $99.5 \%$ pure alumina. Approximately $1.5 \mathrm{~g} \mathrm{LiAlO}_{2}$ powder, placed in alumina crucibles, was exposed under selected experimental conditions. The gaseous atmospheres used during the experiments are reducing $\left(4 \% \mathrm{H}_{2}-\mathrm{N}_{2}\right.$ (balance)) and oxidizing (compressed air). After the completion of the experiments, powder samples were visually examined. Fig. 2 shows while the color of one batch of powder (sample A) changed from white to gray during the exposure to reducing atmosphere, the powder from another batch (sample B) showed little or no change in the color. The gray-color sample A subsequently changed to white after oxidation treatment in air at $700^{\circ} \mathrm{C}$ for 50 hours, similar to reported for $\mathrm{Li}_{2} \mathrm{TiO}_{3}[21]$.

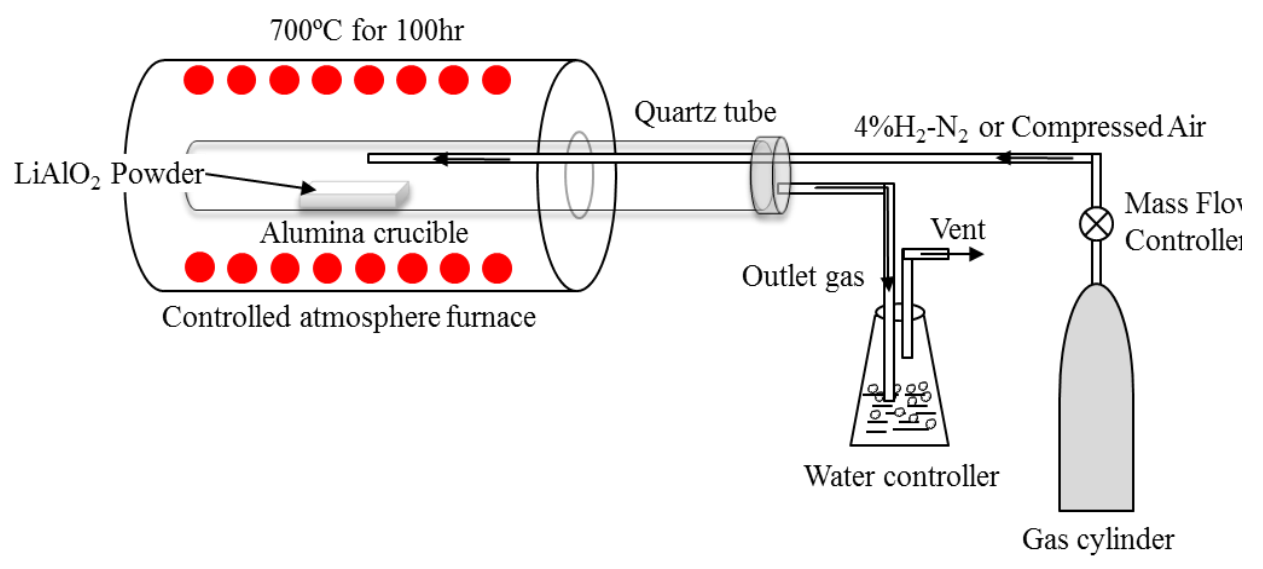

Fig. 1 - Schematic setup for controlled reduction and oxidation of $\mathrm{LiAlO}_{2}$ 
(b)

(c)

(a)

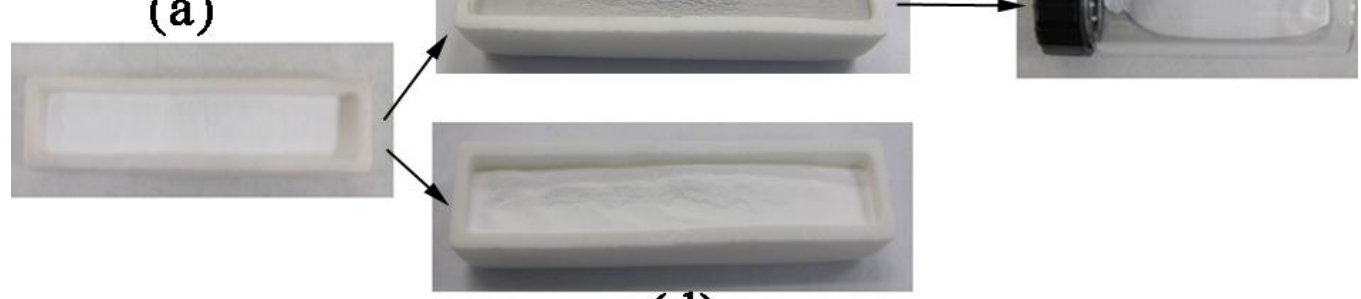

(d)

Fig. 2 - Color change of $\mathrm{LiAlO}_{2}$ powders of as-prepared sample A and B (a), sample A after reduction (b), sample A after re-oxidation (c), and sample B after reduction (d).

\subsection{Characterization}

Lattice structure and compound identification were conducted by X-ray diffraction (XRD) technique at room temperature and high temperature using a Bruker D8 Advance system with $\mathrm{Cu} \mathrm{K} \mathrm{K}_{\alpha}$ radiation $(\lambda=1.5406 \AA)$ and an Anton Paar HTK 1200 oven chamber. In order to identify and understand changes in crystal structure, high-temperature XRD studies of $\mathrm{LiAlO}_{2}$ samples were performed in the temperature range of $25-700^{\circ} \mathrm{C}$ in reducing atmosphere $\left(4 \% \mathrm{H}_{2}\right.$ $\mathrm{N}_{2}$ ) and oxidizing atmosphere (Air) respectively. $\mathrm{LiAlO}_{2}$ powders were supported on an alumina sample holder disk for high temperature XRD. A heating and cooling rate of $5^{\circ} \mathrm{C} / \mathrm{min}$ was used during the experiments with a dwell time of 50 hours at $700^{\circ} \mathrm{C}$. The data were acquired over an angular range $10^{\circ}<2$ theta $<70^{\circ}$ with a scan step of $0.02^{\circ}$ and a specific angular range to determine minor secondary phases with a scan step of $0.01^{\circ}$. Surface morphologies were obtained using an FEI Quanta 250 FEG HRSEM with a field emission source and imaged using an Everhart-Thornley SE (secondary electron) detector with an electron accelerating voltage of $10 \mathrm{kV}$ and a sample height of $10 \mathrm{~mm}$. 
Nitrogen adsorption analysis was performed with Micromeritics ASAP 2020 at $-196^{\circ} \mathrm{C}$. Prior to nitrogen adsorption, the powder was degassed for 12 hours at a temperature of $250^{\circ} \mathrm{C}$. The surface area of the powder was calculated using the Brunauer-Emmett-Teller (BET) equation [22]. The pore volume and pore diameter were determined from the adsorption data of isotherms using the Barrett-Joyner-Halanda (BJH) method. The X-ray Photoelectron Spectroscopy (XPS) measurement has been performed on a PHI 595 Multiprobe system. The Al $\mathrm{K} \alpha$ radiation at $250 \mathrm{~W}$ with a pass energy of $100 \mathrm{eV}$ was measured at a scan rate of $1 \mathrm{eV} / \mathrm{step}$ to study the surface compositions of the $\mathrm{LiAlO}_{2}$ powder and with a pass energy of $50 \mathrm{eV}$ at a scan rate of $0.1 \mathrm{eV} /$ step for higher resolution scan. A take-off angle of $45^{\circ}$ was used in all sample analyses. Accurate binding energies were determined by placing the $\mathrm{C} 1 \mathrm{~s}$ peak at $284.6 \mathrm{eV}$.

\section{Results and Discussion}

\subsection{Crystal Structure by XRD}

The in-situ high-temperature XRD patterns of the powder samples are tabulated in Fig. 3. The major XRD peaks match with that of $\alpha-\mathrm{LiAlO}_{2}$, which is a rhombohedral structure (JCPDS 74-2232) with unit cell parameters of $\mathrm{a}=2.8034 \AA$ and $\mathrm{c}=14.228 \AA$ and a space group of R-3m. XRD patterns obtained at slow scan rate of $5^{\circ}$ per minute (shown in inserts of Fig. 3) show the presence of minor phases of $\mathrm{LiAl}_{2}(\mathrm{OH})_{7} \cdot 2 \mathrm{H}_{2} \mathrm{O}$ (JCPDS 40-0710) and $\mathrm{LiAlO}_{2} \cdot 0.25 \mathrm{H}_{2} \mathrm{O}(\mathrm{JCPDS}$ 21-0487) in the raw powder samples [23, 24]. Although the three minor peaks, observed at 11.7, 23.6 and 36 degree (inserts of Fig. 3), can be assigned to $\mathrm{LiAl}_{2}(\mathrm{OH})_{7} \cdot 2 \mathrm{H}_{2} \mathrm{O}$ and $\mathrm{Li}_{2} \mathrm{Al}_{4}\left(\mathrm{CO}_{3}\right) \cdot 3 \mathrm{H}_{2} \mathrm{O}$ (LACHH, JCPDS 37-0185) phases, relative intensities (372, 277 and 273) of the above peaks are found closer to that of $\mathrm{LiAl}_{2}(\mathrm{OH})_{7} \cdot 2 \mathrm{H}_{2} \mathrm{O}$.

In-situ high-temperature X-ray diffraction patterns for the above powder samples at $700^{\circ} \mathrm{C}$ after 50h exposure in $4 \% \mathrm{H}_{2}-\mathrm{N}_{2}$ and air atmospheres showed that the XRD peaks shift to 
lower angles indicating lattice expansion $[25,26]$. It was also observed that $\mathrm{LiAl}_{2}(\mathrm{OH})_{7} \cdot 2 \mathrm{H}_{2} \mathrm{O}$ disappeared after the completion of the experiments under both reducing or oxidizing atmosphere at $700^{\circ} \mathrm{C}$. Only a small amount of $\gamma-\mathrm{LiAlO}_{2}$ (JCPDS 38-1464) was found to form in the sample A (containing $\operatorname{LiAl}_{2}(\mathrm{OH})_{7} \cdot 2 \mathrm{H}_{2} \mathrm{O}$ ) in the reducing atmosphere only [23].

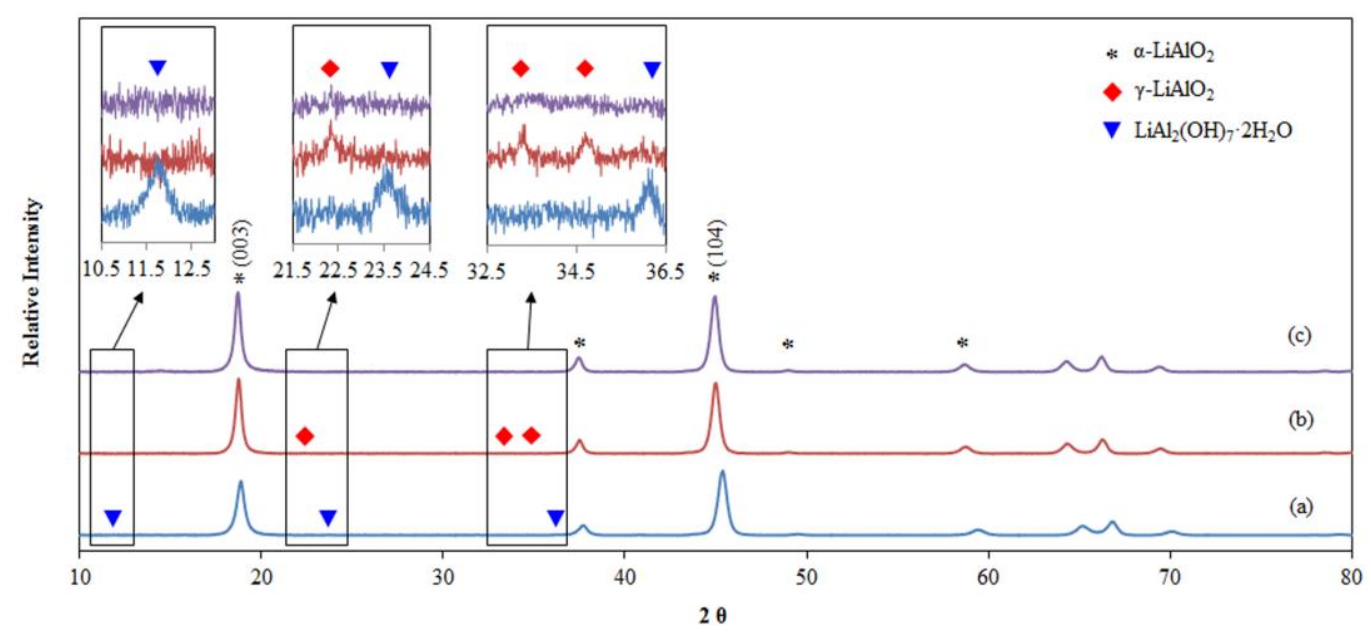

Fig. 3 - X-ray diffraction (HT-XRD) patterns of sample A powder under $4 \% \mathrm{H}_{2}-\mathrm{N}_{2}$ and air atmosphere; (a) room temperature, (b) $700^{\circ} \mathrm{C}$ for 50 hours under $4 \% \mathrm{H}_{2}-\mathrm{N}_{2}$, (c) $700^{\circ} \mathrm{C}$ for 50 hours in air. The inserts show the details of the XRD patterns.

Fig. 4 shows minor peaks of $\mathrm{LiAlO}_{2} \cdot 0.25 \mathrm{H}_{2} \mathrm{O}$ in the sample $\mathrm{B}$ that also disappeared after 50 hours under the reducing atmosphere at $700^{\circ} \mathrm{C}$. The sample showed only the presence of $\alpha$ $\mathrm{LiAlO}_{2}$ and unlike the sample A that showed the formation of $\gamma-\mathrm{LiAlO}_{2}$. The presence of hydrated compounds $\mathrm{LiAlO}_{2} \cdot 0.25 \mathrm{H}_{2} \mathrm{O}$ in $\alpha-\mathrm{LiAlO}_{2}$ has been reported by Pavel, et al. [24] who reported that a sample with a $\mathrm{Li} / \mathrm{Al}$ ratio of 1.0 mainly consist of $\alpha-\mathrm{LiAlO}_{2}$ with a minor $\mathrm{LiAlO}_{2} \cdot 0.25 \mathrm{H}_{2} \mathrm{O}$ phase whereas a sample with lower $\mathrm{Li} / \mathrm{Al}$ ratio of about 0.4 contains $\alpha-\mathrm{LiAlO}_{2}$, $\mathrm{LiAl}_{2}(\mathrm{OH})_{7} \cdot 2 \mathrm{H}_{2} \mathrm{O}$ and $\mathrm{LiAlO}_{2} \cdot 0.25 \mathrm{H}_{2} \mathrm{O}$. The stability of the powder samples were analyzed by 
using the integrated intensity ratio $I_{(003)} / I_{(104)}$ of (003) and (104) peaks indicative of cationic mixing in the lattice and a measure of lattice stability $[27,28]$. If $I_{(003)} / I_{(104)}$ is lower than 1.1, the lattice structure is less stable due to the more cationic disorder, which indicates that many $\mathrm{Al}^{3+}$ are mixed with $\mathrm{Li}^{+}$in $3 \mathrm{a}$ sites [29]. The integrated intensity ratio $I_{(003)} / I_{(104)}$ of powder sample A decreased from 0.84 to 0.74 during the reduction treatment, indicating an increase of disorder between $\mathrm{Li}^{+}$and $\mathrm{Al}^{3+}$, meaning a high concentration of $\mathrm{Al}^{3+}$ ions in the $\mathrm{Li}$ interlayer sites. However, after heating under the oxidizing atmosphere, the ratio of $I_{(003)} / I_{(104)}$ increased to 0.98 , due to an increase in crystallinity and cationic ordering. The integrated intensity ratio $I_{(003)} / I_{(104)}$ of powder sample B remains essentially at 1.0 regardless of the reduction treatment. This indicates the sample B has a higher cationic ordering and is more resistant to increase in disordering even under the reduction treatment.

Above processes are schematically presented in Fig. 5. The formation of hydrated oxide along with absorbed water on the $\alpha-\mathrm{LiAlO}_{2}$ and their subsequent dissociation and conversion to $\gamma-\mathrm{LiAlO}_{2}$ is presented at elevated temperature.

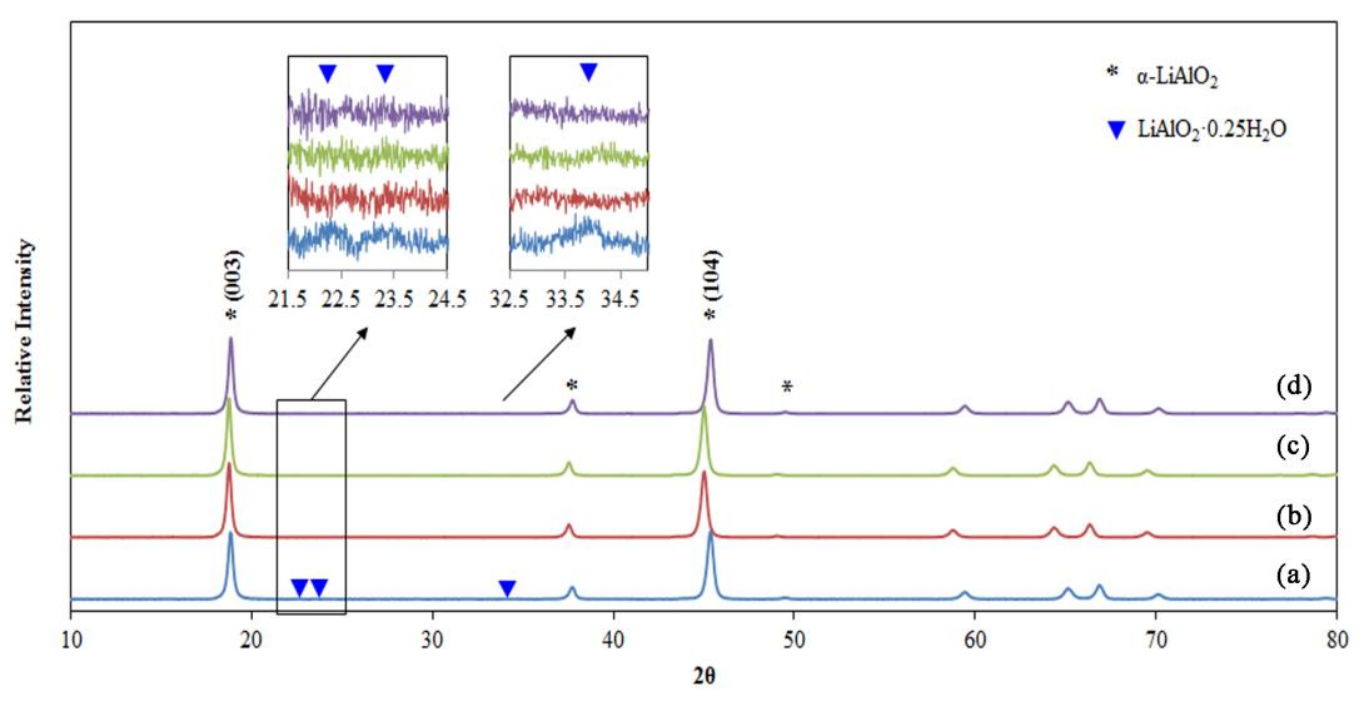


Fig. 4 - High temperature X-ray diffraction (HT-XRD) pattern of sample B powder under 4\% $\mathrm{H}_{2}-\mathrm{N}_{2}$ atmosphere; room temperature, after 20 hours at $700^{\circ} \mathrm{C}$, after 50 hours at $700^{\circ} \mathrm{C}$ and after cool down to $30^{\circ} \mathrm{C}$. The inserts show the details of the XRD patterns.

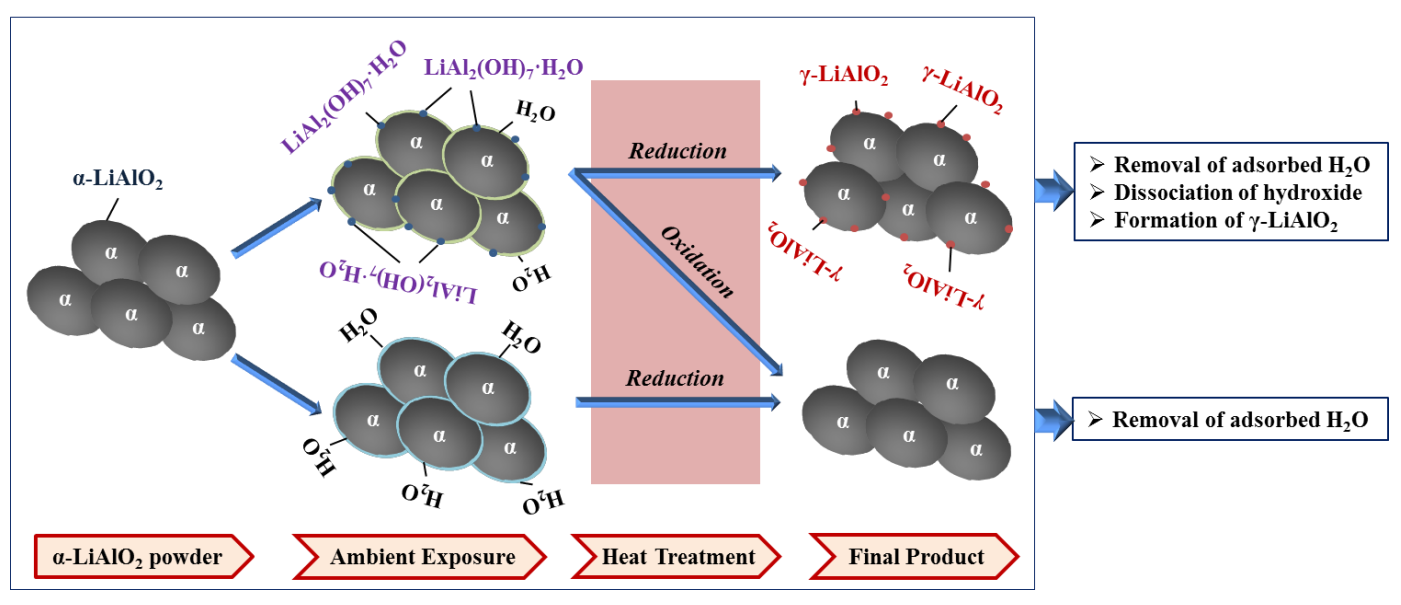

Fig. 5 - A schematic depicting surface reaction processes on $\mathrm{LiAlO}_{2}$ powder during treatment in oxidizing and reducing atmospheres.

\subsection{Powder Surface Composition by XPS}

The surface chemistry of the powder samples (depth 0-10 nm) were determined by XPS (Table 1). The Li/Al ratio on the surface of the sample A is 0.83 , indicating $\mathrm{Li}^{+}$deficiency on the $\mathrm{LiAlO}_{2}$ particle surface. The Li deficiency may be attributed to the presence of $\mathrm{LiAl}_{2}$ $(\mathrm{OH})_{7} \cdot 2 \mathrm{H}_{2} \mathrm{O}$ (low $\mathrm{Li} / \mathrm{Al}$ ratio), as confirmed by $\mathrm{XRD}$ (Fig. 3). The $\mathrm{Li} / \mathrm{Al}$ ratio of the surface decreases to 0.66 during the exposure to the reducing atmosphere, suggesting that a large quantity of $\mathrm{Li}^{+}$ions located on the surface is removed. The powder also showed grey discoloration. The exposure of powder samples to the oxidizing atmosphere at $700^{\circ} \mathrm{C}$, on the other hand, led to an increase in the surface $\mathrm{Li} / \mathrm{Al}$ ratio to 0.87 without visual color change. In comparison, $\mathrm{LiAlO}_{2} \cdot 0.25 \mathrm{H}_{2} \mathrm{O}(\mathrm{Li} / \mathrm{Al}=1 / 1)$ has been observed in the sample B (Fig. 4) and may 
explain the higher surface Li/AL ratio (0.96), as shown in Table 1. The sample B also showed less decrease of the surface $\mathrm{Li} / \mathrm{Al}$ ratio during the reduction treatment compared to the sample A. The power remained white. In conclusion, a higher Li/Al ratio may indicate less Li-deficient surface minor phases and/or more stable stoichiometry that have prevented the color change of the power sample B [30].

Table 1. The $\mathrm{Li} / \mathrm{Al}$ ratio of $\mathrm{LiAlO}_{2}$ samples of as-prepared sample A, Sample A exposed to $4 \%$ $\mathrm{H}_{2}-\mathrm{N}_{2}$ atmosphere at $700^{\circ} \mathrm{C}$, Sample A exposed to air atmosphere at $700^{\circ} \mathrm{C}$, as-prepared sample B and sample B exposed to $4 \% \mathrm{H}_{2}-\mathrm{N}_{2}$ atmosphere at $700^{\circ} \mathrm{C}$.

\begin{tabular}{lcc}
\hline Samples & Li/Al ratio by XPS & Intensity ratio \\
& & $\mathrm{I}_{(003)} / \mathrm{I}_{(104)}$ \\
\hline As-received sample A & $0.83 \pm 0.02$ & $0.84 \pm 0.02$ \\
Sample A after reduction & $0.66 \pm 0.02$ & $0.74 \pm 0.01$ \\
Sample A after oxidation & $0.87 \pm 0.03$ & $0.98 \pm 0.02$ \\
As-received sample B & $0.96 \pm 0.03$ & $1.02 \pm 0.02$ \\
Sample B after reduction & $0.85 \pm 0.03$ & $1.01 \pm 0.02$
\end{tabular}

\subsection{High resolution XPS Al 2p spectra}

Binding energy (BE) shift of the $\mathrm{Al} 2 \mathrm{p}$ peaks for the sample A after the reduction and oxidation treatments is shown Fig. 6. For the as-prepared sample A, the spectrum was deconvoluted into two peaks at 74.3 and $72.9 \mathrm{eV}$. The higher peak at $74.3 \mathrm{eV}$ was assigned to the formation of Al-O bond [31]. The energy value of lower peak was 72.9, which is $0.5 \mathrm{eV}$ higher than that of metallic Al. The binding energy of a small metal cluster was reported to shift to higher value than the bulk metal $[32,33,34]$. After the reduction treatment at $700^{\circ} \mathrm{C}$, a shift of 
the binding energy of $\mathrm{Al} 2 \mathrm{p}$ to 73.9 [35] and $72.8 \mathrm{eV}$ [36] was observed. The intensity of Al-O decreased and that of metallic Al considerably increased after the exposure to the reducing atmosphere at $700^{\circ} \mathrm{C}$. Similar observation has been reported for $\mathrm{Rh} / \mathrm{Al}_{2} \mathrm{O}_{3}$ catalyst treated in a reducing condition by M. Zimowska et al. [37]. After the oxidation treatment, an additional asymmetric component appeared at 75.5 and $76.9 \mathrm{eV}$ while the peaks of metallic $\mathrm{Al}$ decreased. This high BE peaks at 75.5 and $76.9 \mathrm{eV}$ are assigned to fully-coordinated and under-coordinated $\mathrm{Al}^{3+}$ in $\mathrm{Al}_{2} \mathrm{O}_{3}[38,39]$. The oxidation of the metallic aluminum is confirmed by the decrease in Al-Al bond around $73 \mathrm{eV}$ [40]. This indicates that metallic aluminum shifted toward higher binding energy due to the oxidation of the surface enriched metallic aluminum atoms while exposure to the oxidizing air atmosphere [41]. 


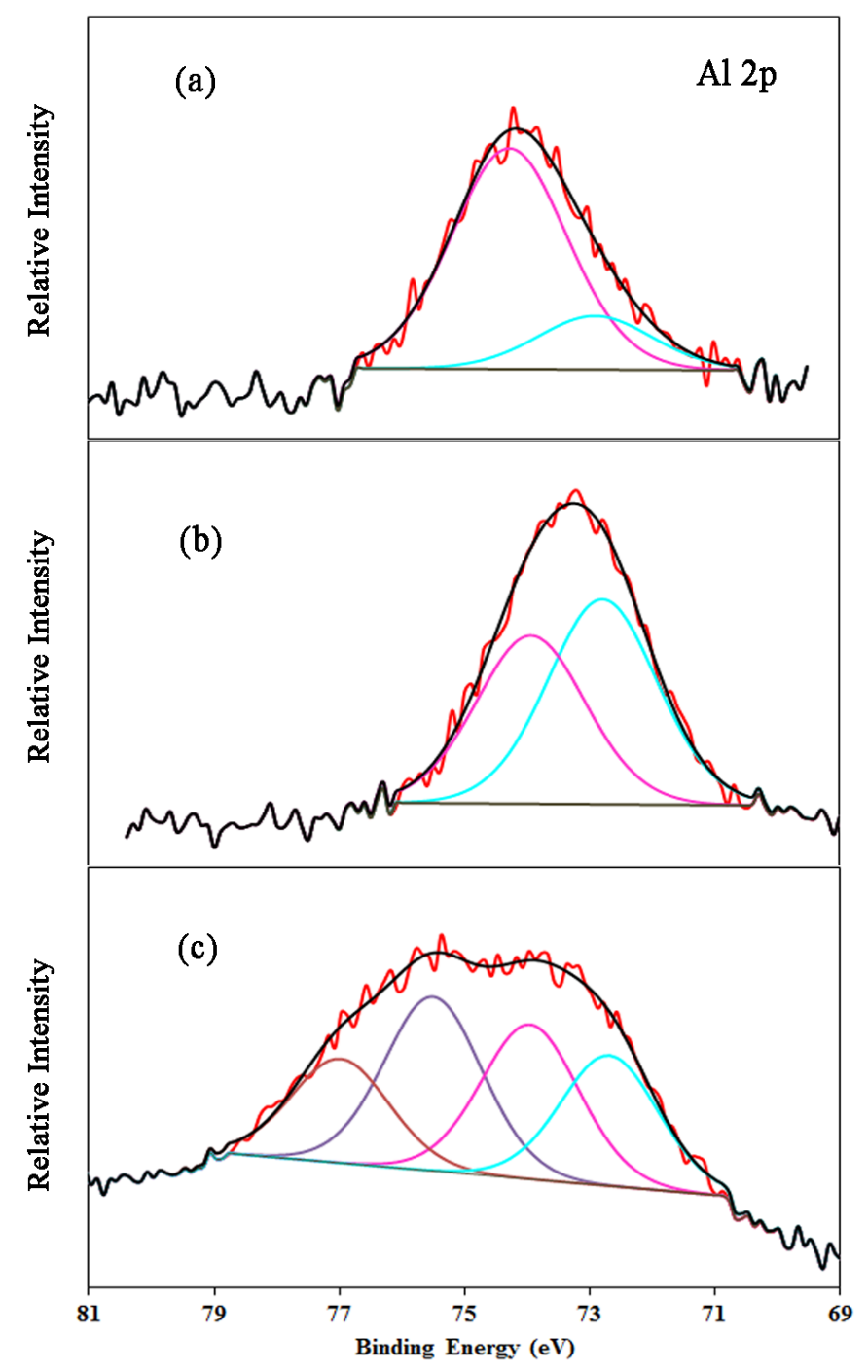

Fig. 6 - High resolution XPS Al 2p spectra of samples A as-prepared (a), after reduction (b), and after oxidation (c).

\subsection{Morphologies by SEM}

A typical low-magnification surface morphology of the $\mathrm{LiAlO}_{2}$ (sample A) powders obtained by FESEM is shown in Fig. 7 (a). The powder morphology shows the presence of dispersed microspheres of $\sim 20 \mu \mathrm{m}$ diameter with very porous surface while powder sample B displays similar micro but relatively less porous spherical morphology as shown in Fig. 7 (b). Fig. 
8 shows the high-magnification surface morphology of the samples before and after the reduction/oxidation treatments at $700^{\circ} \mathrm{C}$ for 100 hours. For the sample A, it is observed that microspheres consist of agglomerated nanoparticles of spherical and plate-like loosely interconnected particles generating nano- and micron-size pores. The above observation is consistent with the findings of $\mathrm{H}$. Xiao et al. [42] who reported that porous $\mathrm{LaFeO}_{3}$ microspheres exhibit much higher response to reducing gas than denser $\mathrm{LaFeO}_{3}$ particles. The sample $\mathrm{B}$ powder in Fig. 8 (d) shows that the microsphere is also assembled from a large amount of interconnected uniform nanoparticles with only micron-sized pores.
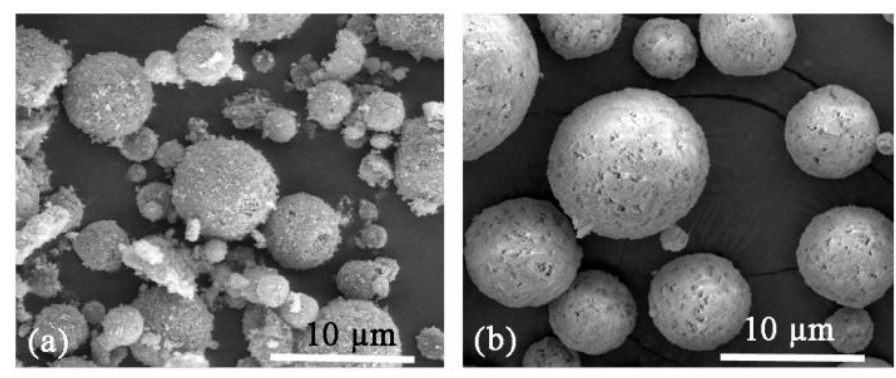

Fig. 7 - Low-magnification FESEM images of the $\mathrm{LiAlO}_{2}$ Sample A (a) and Sample B (b)

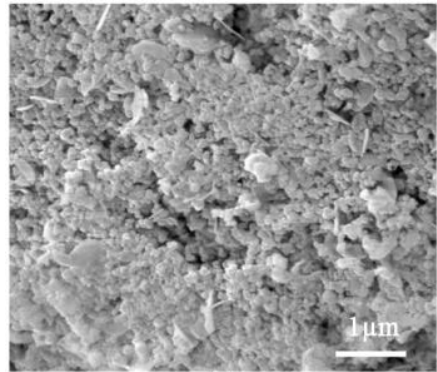

(a)

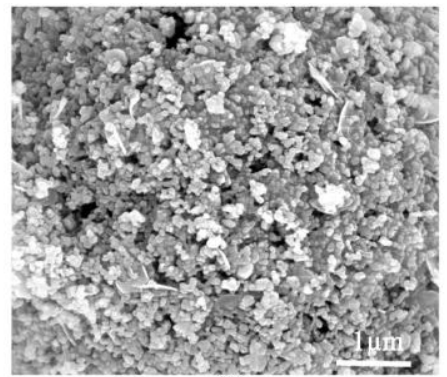

(b)

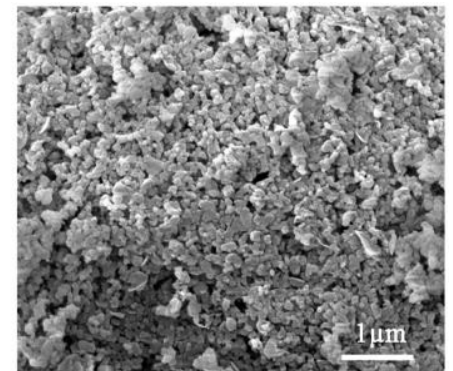

(c)

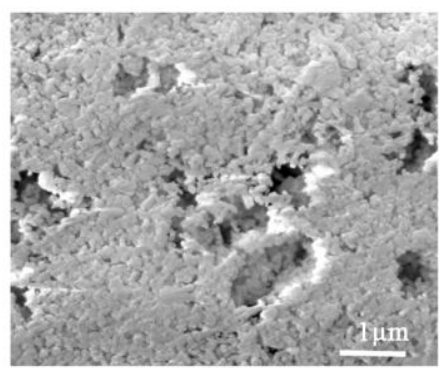

(d)

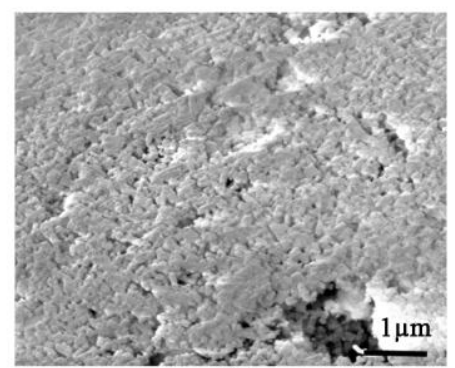

(e) 
Fig. 8 - High-magnification FESEM images of the $\mathrm{LiAlO}_{2}$ samples. (a) as-prepared sample A, (b) sample A after reduction, (c) sample A after oxidation, (d) as-prepared sample B and (d) sample B after reduction.

\subsection{Surface Area and Pore Size Distribution}

Nitrogen adsorption-desorption measurements were carried out in order to study the surface area and pore-size distribution of the powder samples exposed to both reducing and oxidizing atmospheres. $\mathrm{N}_{2}$ adsorption isotherms of the powder sample A and B as prepared and after reduction are shown in Fig. 9 (a-d). All samples exhibited a typical type II isotherm, characteristic of micro- and mesoporous materials [43]. The adsorbed amount of $\mathrm{N}_{2}$ decreased from $95.9 \mathrm{~cm}^{3} / \mathrm{g}$ on the sample A to $68.9 \mathrm{~cm}^{3} / \mathrm{g}$ (a decrease of $28.2 \%$ ) after the reduction treatment. The sample B (before and after reduction) shows that the adsorbed amount of $\mathrm{N}_{2}$ decreased from $87.2 \mathrm{~cm}^{3} / \mathrm{g}$ to $77.6 \mathrm{~cm}^{3} / \mathrm{g}$ (a decrease of $11.0 \%$ ), indicating that adsorption is easier on the as-prepared powders. Absorption and surface coverage is also favored on sample A which shows a more porous structure, when compared with the sample B that contains more compact interconnected structure.

Pore size distributions obtained by the BJH method as shown in Fig. 10 indicate the

presence of pores in the size range of $25 \AA$ in both sample A and B. The pore volume increases and widen after the high temperature heat treatment. While the pore volume below $25 \AA$ of pore diameter slightly increase in sample A, such pores and pore volume remain unchanged in sample $\mathrm{B}$ before and after reduction.

Specific surface area of the sample A and B were calculated according to nitrogen adsorption measurements. Table 2 summarizes the nitrogen sorption data of the sample A and B. 
The sample A has a sum of meso- and micro- pores' volume equal to $0.006 \mathrm{~cm}^{3} / \mathrm{g}$. After the reduction treatment, the pore volume increases to $0.007 \mathrm{~cm}^{3} / \mathrm{g}$ due to the removal of $\mathrm{LiAl}_{2}$ $(\mathrm{OH})_{7} \cdot 2 \mathrm{H}_{2} \mathrm{O}$ and formation of $\gamma-\mathrm{LiAlO}_{2}$, as shown in Fig.3. The surface area increases by $6.7 \%$, which is also a result of increase in the meso- and micro-pore volume. The sample B showed only slight change in the surface area $(0.6 \%)$ and the pore volume (both $0.005 \mathrm{~cm}^{3} / \mathrm{g}$ ) after the reduction treatment. Stable behavior of the powder is considered to be related to the presence of denser surface and higher Li/Al integrated ratio. The presence of the hydrated oxides, crystalline water, absorbed water, and $\mathrm{Li} / \mathrm{Al}$ ratio all influences the mesopores, specific surface area pore volume as well as phase stability at elevated temperatures.
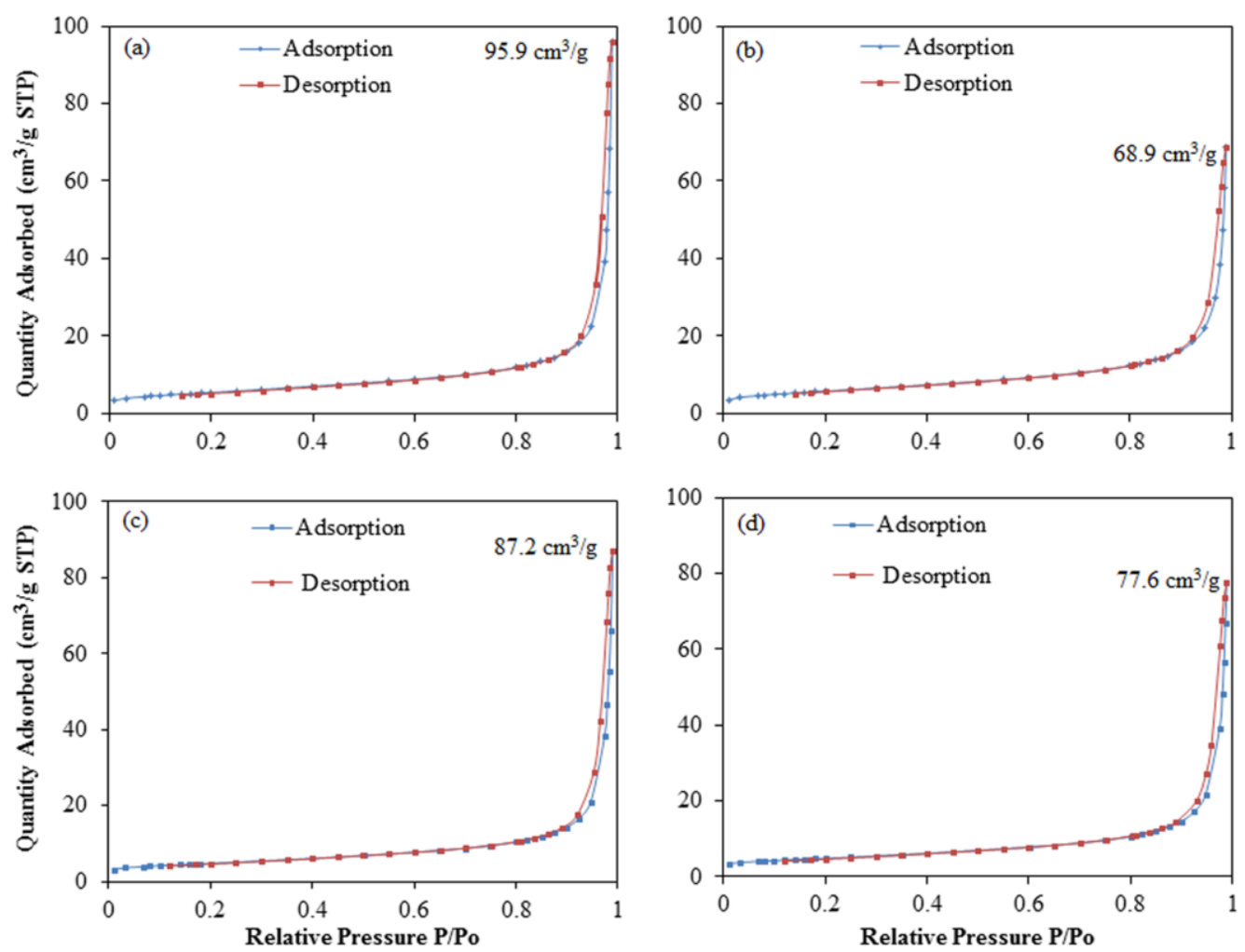

Fig. 9 - Adsorption isotherm patterns of the $\mathrm{LiAlO}_{2}$ powders: (a) as-prepared sample A powder, (b) sample A after reduction, (c) as-prepared sample B, and (d) B1 powder, and (d) sample B after reduction. 


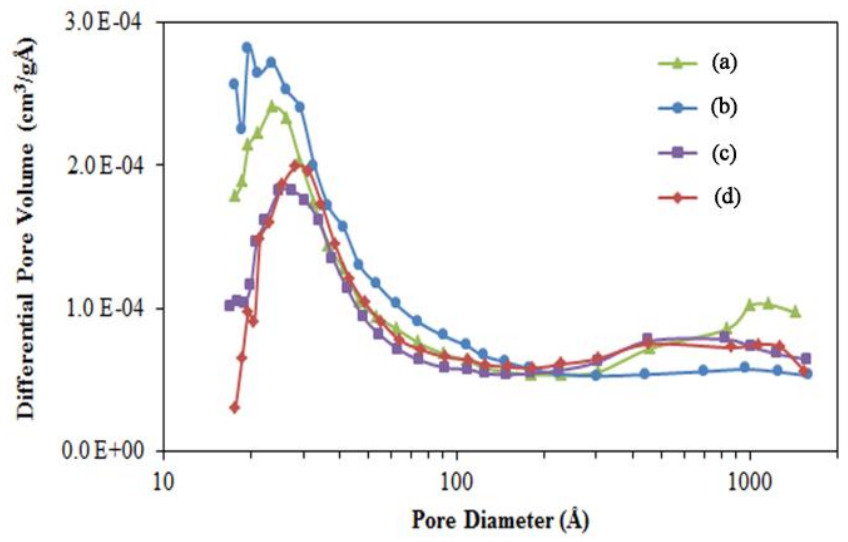

Fig. 10 - BJH pore size distribution of the $\mathrm{LiAlO}_{2}$ powders: (a) as-prepared sample A powder, (b) sample A after reduction, (c) as-prepared sample B, and (d) sample B after reduction.

Table 2. BET surface area and micro- and meso-pore volume of $\mathrm{LiAlO}_{2}$ samples of as-prepared sample A, Sample A exposed to $4 \% \mathrm{H}_{2}-\mathrm{N}_{2}$ atmosphere at $700^{\circ} \mathrm{C}$, as-prepared sample $\mathrm{B}$ and sample B exposed to $4 \% \mathrm{H}_{2}-\mathrm{N}_{2}$ atmosphere at $700^{\circ} \mathrm{C}$.

\begin{tabular}{lll}
\hline Samples & $\begin{array}{l}\text { BET Surface Area } \\
\text { Change }(\%)\end{array}$ & $\begin{array}{l}\text { V micro + V meso } \\
\left(\mathrm{cm}^{3} / \mathrm{g}\right)\end{array}$ \\
\hline As-prepared sample A & $100 \%$ & $0.0056 \pm 0.0001$ \\
Sample A after reduction & $+6.7 \%$ & $0.0066 \pm 0.0001$ \\
As-prepared sample B & $100 \%$ & $0.0048 \pm 0.0001$ \\
Sample B after reduction & $-0.6 \%$ & $0.0050 \pm 0.0001$ \\
\hline BET surface area is $15-25 \mathrm{~m}^{2} / \mathrm{g}$ &
\end{tabular}

\section{Conclusions}

The XRD analysis show that the as-prepared $\alpha-\mathrm{LiAlO}_{2}$ samples contain small amounts of $\mathrm{LiAl}_{2}(\mathrm{OH})_{7} \cdot 2 \mathrm{H}_{2} \mathrm{O}$ phase in the sample $\mathrm{A}$ and $\mathrm{LiAlO}_{2} \cdot 0.25 \mathrm{H}_{2} \mathrm{O}$ phase in the sample $\mathrm{B}$. The 
XPS surface analysis of the $\alpha-\mathrm{LiAlO}_{2}$ powder shows Li-deficiency exists on the surface and becomes more deficient upon treatment in the reducing atmosphere. After exposure to the reducing atmosphere, $\mathrm{LiAl}_{2}(\mathrm{OH})_{7} \cdot 2 \mathrm{H}_{2} \mathrm{O}$ peak disappeared followed by the formation of $\gamma$ $\mathrm{LiAlO}_{2}$ phase. A decrease in the integrated intensity ratio $I_{(003)} / I_{(104)}$ of (003) and (104) peaks from 0.84 to 0.74 for the sample $\mathrm{A}$ after exposure to the reducing atmosphere indicates a higher degree of the cationic disorder and relatively poor structural stability under reducing environment . On the other hand, the sample B showed relatively less $I_{(003)} / I_{(104)}$ of (003) and (104) peaks and Li/Al ratio changes, indicating less cationic disorder and hence improved structural stability. Apparently a reducing environment may promote cationic disorder and surface non-stoichiometry that reduce powder structural thermal stability. The above inference may be supported by the powder color change under a reducing atmosphere. The presence of hydrated oxide phases $\mathrm{LiAl}_{2}(\mathrm{OH})_{7} \cdot 2 \mathrm{H}_{2} \mathrm{O}$ and $\mathrm{LiAlO}_{2} \cdot 0.25 \mathrm{H}_{2} \mathrm{O}$, crystalline water, and $\mathrm{Li} / \mathrm{Al}$ ratio influences the thermal stability during exposure to elevated temperatures. To fully understand the $\mathrm{LiAlO}_{2}$ under MCFC environments, further investigation in the presence of electrolyte needs to be conducted.

\section{Acknowledgements}

Authors acknowledge financial support from the US Department of Energy under contract DE-EE0006606. Dr. Heng Zhang at the Institute for Material Science, University of Connecticut is acknowledged for helpful discussion on XPS analysis. Center for Clean Energy Engineering at the University of Connecticut is acknowledged for providing laboratory support and the use of characterization facility. 


\section{Reference}

1. Danek V, Tarniowy M, Suski L. Kinetics of the $\alpha \rightarrow \gamma$ phase transformation in $\mathrm{LiAlO}_{2}$ under various atmospheres within the 1073-1173 K temperatures range. J Mater Sci 2004;39:2429-35.

2. Nishikawa M, Baba A, Kawamura Y. Tritium inventory in a $\mathrm{LiAlO}_{2}$ blanket. J Nucl Mater 1997;246:1-8.

3. Remick RJ, Wheeler D, Singh P. Molten carbonate fuel cell. MCFC/PAFC R\&D Workshop; 2009 Nov 16.

4. Dronskowski R. Reactivity and acidity of $\mathrm{Li}$ in $\mathrm{LiAlO}_{2}$ phases. Inorg Chem 1993;32:1-9.

5. Takizawa K, Hagiwara A. The transformation of $\mathrm{LiAlO}_{2}$ crystal structure in molten $\mathrm{Li} / \mathrm{K}$ carbonate. J Power Sources 2002;109:127-35.

6. Lei L, He D, Zou Y, Zhang W, Wang Z, Jiang M, Du M. Phase transitions of $\mathrm{LiAlO}_{2}$ at high pressure and high temperature. J Solid State Chem 2008;181:1810-5.

7. Finn PA. The effects of different environments on the thermal stability of powdered samples of $\mathrm{LiAlO}_{2}$. J Electrochem Soc 1980;127:236-8.

8. Terada S, Nagashima I, Higaki K, Ito Y. Stability of $\mathrm{LiAlO}_{2}$ as electrolyte matrix for molten carbonate fuel cells. J Power Sources 1998;75:223-9.

9. Tanimoto K, Yanagida M, Kojima T, Tamiya Y, Matsumoto H, Miyazaki Y. Long-term operation of small-sized single molten carbonate fuel cells. J Power Sources 1998;72:7782.

10. Batra VS, Maudgal S, Bali S, Tewari PK. Development of alpha lithium aluminate matrix for molten carbonate fuel cell. J Power Sources 2002;112:322-5. 
11. Dhabekar B, Raja EA, Menon S, Gundu Rao TK, Kher RK, Bhatt BC. ESR, PL and TL studies of $\mathrm{LiAlO}_{2}: \mathrm{Mn} / \mathrm{Ce}$ phosphor. Radiat Meas 2008;43: 291-4.

12. Kutty TRN, Nayak M. Cation coordination and $\mathrm{Fe}^{3+}$ luminescence in $\mathrm{LiAlO}_{2}$ polymorphs prepared by a hydrothermal method. Mater Res Bull 1999;34(2):249-62.

13. Jimenez-Becerril J, Bosch P, Bulbulian S. Synthesis and characterization of $\gamma-\mathrm{LiAlO}_{2}$. J Nucl Mater 1991;185:304-7.

14. Kinoshita K, Sim JW, Kucera GH. Synthesis of fine particle size lithium aluminate for application in molten carbonate fuel cells. Mater Res Bull 1979;14:1357-68.

15. Khomane RB, Agrawal A, Kulkarni BD. Synthesis and characterization of lithium aluminate nanoparticles. Mater Lett 2007;61:4540-4.

16. Choi HJ, Lee JJ, Hyun SH, Lim HC. Cost-effective synthesis of $\alpha$-LiAlO 2 powders for molten carbonate fuel cell matrices. Fuel cells 2009;9:605-12.

17. Turner CW, Clatworthy BC, Gin AHY. The preparation of lithium aluminate by the hydrolysis of lithium and aluminum alkoxides. The International Symposium on Fabrication \& Properties of Lithium Ceramics, Pittsburgh, USA;1987.

18. Ravindranathan P, Komarneni S, Roy R. Synthesis of lithium aluminate, mullite and coloured zirconia by a combustion process. J Mater Sci Lett 1993;12:369-71.

19. Li F, Hu K, Li J, Zhang D, Chen G. Combustion synthesis of $\gamma$-lithium aluminate by using various fuels. J Nucl Mater 2002;300:82-8.

20. Wen Z, Gu Z, Xu X, Zhu X. Research on the preparation, electrical and mechanical properties of $\gamma-\mathrm{LiAlO}_{2}$ ceramics. J Nucl Mater 2004;329-333:1283. 
21. Hoshino T, Kawamura H, Dokiya M, Takahashi Y, Terai T, Yamawaki M. Nonstoichiometry of $\mathrm{Li}_{2} \mathrm{TiO}_{3}$ under hydrogen atmosphere conditions. J Nucl Mater 2004;329$33: 1300-4$

22. Hill T L. Adsorption from a one-dimensional lattice gas and the Brunauer-Emmett-Teller equation. Proceedings of the National Academy of Sciences of the United States of America; 1996;93:14328-32.

23. Wen ZY, Lin ZX, Chen KG. Introduction of sodium to layered double hydroxides $\mathrm{LiAl}_{2}(\mathrm{OH})_{7} \cdot 2 \mathrm{H}_{2} \mathrm{O}$. J Mater Sci Lett 1996;15:105.

24. Pavel OD, Zavoianu R, Birjega R. Angelescu E. Impact of the memory effect on the catalytic activity of Li-Al hydrotalcite-like compounds for the cyanoethylation reaction. Mater Res Bull 2010;45:1106-11.

25. Kerstan M, Muller M, Russel C. Binary, ternay and quaternary silicates of $\mathrm{CaO}, \mathrm{BaO}$ and $\mathrm{ZnO}$ in high thermal expansion seals for solid oxide fuel cells studied by hightemperature X-ray diffraction (HT-XRD). Mater Res Bull 2011;46:2456-63.

26. Shu Q, Zhang J, Liu J. The high temperature phase transitions of orthorhombic $\mathrm{La}_{0.95} \mathrm{MnO}_{3}$. J. Alloys Compd. 2005;390:240-4.

27. Ohzuku T, Ueda A, Nagayama M. Electrochemistry and structural chemistry of $\mathrm{LiNiO}_{2}$ (R-3m) for 4 volt secondary lithium cells. J Electrochem Soc 1993;140:1862-70.

28. Gu YJ, Chen YB, Liu HQ, Wang YM, Wang CL, Wu HK. Structural characterization of layered $\mathrm{LiNi}_{0.85-\mathrm{x}} \mathrm{Mn}_{\mathrm{x}} \mathrm{Co}_{0.15} \mathrm{O}_{2}$ with $\mathrm{x}=0,0.1,0.2$ and 0.4 oxide electrodes for $\mathrm{Li}$ batteries. J Alloys Comp 2011;509:7915-21.

29. Kim J, Fulmer P, Manthiram A. Synthesis of $\mathrm{LiCoO}_{2}$ cathodes by an oxidation reaction in solution and their electrochemical properties. Mater Res Bull 1999;34:571-9. 
30. Hoshino T, Dokiya M, Terai T, Takahashi Y, Yamawaki M. Non-stoichiometry and its effect on thermal properties of $\mathrm{Li}_{2} \mathrm{TiO}_{3}$. Fusion Eng Des 2002;61-62:353-60.

31. Wei T, Yan F, Tian J. Characterization and wear- and corrosion-resistance of microarc oxidation ceramic coatings on aluminum alloy. J Alloys Comp 2005;389:169-76.

32. Takasu Y, Unwin R, Tesche B, Bradshaw AM. Photoemission from palladium particle arrays on an amorphous silica substrate. Surf Sci 1978;77:219-32.

33. Mason MG. Electronic structure of supported small metal clusters. Phys Rev $1983 ; B 27: 748-62$.

34. Parmigiani F, Kay E, Bagus PS, Nelin CJ. Core binding energies for clusters deposited on different insulating substrates: ESCA spectra and theoretical electronic structure studies. J Electron Spectrosc Relat Phenom 1985;36:257-67.

35. Patil NS, Jha R, Uphade BS, Bhargava SK, Choudhary VR. Epoxidation of styrene by anhydrous $t$-butyl hydroperoxide over gold supported on $\mathrm{Al}_{2} \mathrm{O}_{3}, \mathrm{Ga}_{2} \mathrm{O}_{3}, \mathrm{In}_{2} \mathrm{O}_{3}$ and $\mathrm{Tl}_{2} \mathrm{O}_{3}$. Appl. Cataly. 2004;A275:87-93.

36. Qi B, Agnarsson B, Gothelid M, Olafsson S, Gislason HP. High-resolution X-ray photoemission spectroscopy study of AlN nano-columns grown by nitridation of $\mathrm{Al}$ nano-squares on Si (111) substrates with ammonia. Thin Solid Films 2010;518:3632-9.

37. Zimowska M, Wagner JB, Dziedzic J, Camra J, Borzecka-Prokop B, Najbar M. Some aspects of metal-support strong interactions in $\mathrm{Rh} / \mathrm{Al}_{2} \mathrm{O}_{3}$ catalyst under oxidizing and reducing conditions. Chem Phys Lett 2006;417:137-42.

38. Rueda F, Mendialdua J, Rodriguez A, Casanova R, Barbaux Y, Gengembre L, Jalowiecki L. Characterization of Venezuelan laterites by X-ray photoelectron spectroscopy. J Electron Spectrosc Relat Phenom 1996;82:135-43. 
39. Makarowicz A, Bailey CL, Weiher N, Kemnitz E, Schroeder SLM, Mukhopadhyay S, Wander A, Searle BG, Harrison NM. Electronic structure of Lewis acid sites on high surface area aluminum fluorides: a combined XPS and $a b$ initio investigation. Phys Chem Chem Phys 2009;11:5664-73.

40. Paparazzo E. XPS analysis of iron aluminum oxide systems. Appl Surf Sci 1986;25:1-12.

41. Graupner H, Hammer L, Heinz K, Zehner DM. Oxidation of low-index FeAl surfaces. Surf Sci 1997;380:335-51.

42. Xiao H, Xue C, Song P, Li J, Wang Q. Preparation of porous $\mathrm{LaFeO}_{3}$ microspheres and their gas-sensing property. Appl Surf Sci 2015;337:65-71.

43. Storch S, Bretinger H, Maier WF. Characterization of micro- and mesoporous solids by physisorption methods and pore-size analysis. Appl Catal 1998;A174:137-46. 